\title{
Analysis of p53 expression and proliferative assessment using PCNA in localized prostate carcinoma
}

\section{K.R.M. Leite1, M. Srougi ${ }^{2}$,} L.J. Nesralhah' and L.H. Camara-Lopes ${ }^{1}$

\author{
${ }^{1}$ Laboratório de Patologia Cirúrgica e Molecular, Hospital Sírio Libanês, \\ São Paulo, SP, Brasil \\ 2Divisão de U rologia, Escola Paulista de M edicina, \\ Universidade Federal de São Paulo, São Paulo, SP, Brasil
}

\section{Correspondence \\ K.R.M. Leite \\ Rua Dona Adma Jafet, 91 \\ 01308-050 São Paulo, SP \\ Brasil \\ Fax: + 55-11-231-2249 \\ E-mail: ramosk@ibm.net \\ Publication supported by FAPESP.}

Received July 3, 1998

Accepted November 17, 1998

\section{Abstract}

The surgical specimens from 51 men submitted to radical prostatectomy for localized prostate cancer were examined by immunohistochemistry using proliferation cell nuclear antigen (PCNA) monoclonal antibody to evaluate the proliferative index (PI). The relationship between PI, biological variables and p53 protein expression was evaluated by immunohistochemistry. PI was low in invasive localized prostate carcinoma (mean, 12.4\%) and the incidence of PCNA-positive cells was significantly higher in tumors with $\mathrm{p} 53$ expression $(\mathrm{P}=$ $0.0226)$. There was no statistical difference in PCNA values when biological parameters such as Gleason score, tumor volume, extraprostatic involvement, seminal vesicle infiltration or lymph node metastasis were considered. We conclude that proliferative activity is usually low in prostate carcinoma but is correlated with p53 immune staining, indicating that p53 is important in cell cycle control in this neoplasm.

\section{Introduction}

The assessment of proliferation is important to characterize the malignant phenotype and biological behavior of neoplasms. Several techniques such as tritium $\left[{ }^{3} \mathrm{H}\right]$-thymidine radioautography, 5-bromo- and 5-iododeoxyuridine (Brdu) immunohistochemistry, mitotic figure counts, S-phase evaluation by flow cytometry or the observation of living cells in tissue culture by phase contrast microscopy are some of the tools to determine the proliferative activity. Proliferation cell nuclear antigen (PCNA) is an auxiliary enzyme protein for DNA polymerase-delta in-

\section{Key words}

- Prostate carcinoma

- p53

- Proliferating cell nuclear antigen

- PCNA volved in DNA synthesis during the S-phase of the cell cycle $(1,2)$. The PCNA antibody can be used in formalin-fixed, paraffin-embedded tissue to evaluate cell proliferation. Cells in the late G1 and S phase show strong nuclear staining, which is not detected in mitotic or arrested cells. In prostate carcinoma the proliferative activity has been related to disease progression (3) and risk of death (4) and has been used to demonstrate highgrade prostatic intraepithelial neoplasia (HGPIN) as a precursor of the invasive carcinoma (5). p53 is a tumor suppressor gene important in cell cycle control, DNA repair and apoptosis (6). Its role in prostate cancer has been 
evaluated by many investigators since Isaacs (7) described a suppression of tumorigenesis in prostate cancer cell lines by transfecting wild type $\mathrm{p} 53$. The most common alteration in the p53 gene, located in the $17 \mathrm{p} 13.1$ chromosome, is the missense mutation, that produces a protein with extended half-life that can be detected by immunohistochemistry using monoclonal antibodies (8). p53 immunostaining has been related to high histological grade, DNA aneuploidy and proliferation (9). Others consider the p53 mutation to be a late event related to androgen-independent growth (10). The aim of the present study was to evaluate proliferation, its relation to p53 expression and other biological variables. A retrospective study using paraffinembedded tissue from 51 men submitted to radical prostatectomy for localized prostate cancer was performed using anti-PCNA antibody (PC10) for the evaluation of proliferative activity. The PI, expressed as percent of positive cells in 500 cells sampled, was compared with p53 protein expression, Gleason score, tumor volume, extraprostatic involvement, seminal vesicle infiltration and lymph node metastasis.

\section{Material and Methods}

Fifty-one patients with prostate cancer clinically staged as T1 and T2N0M0 (11) were submitted to radical prostatectomy between March and June 1997 at the Sírio Libanês Hospital. The specimens were fixed in buffered formalin for 4 to $16 \mathrm{~h}$. The entire surgical margin was stained with India ink. The left and right lobes were separated, 3$\mathrm{mm}$ transversal serial sections were obtained from each lobe and the whole tissue was submitted to histological examination. Sections of bladder neck, prostate apex, seminal vesicles and pelvic lymph nodes were also examined. An average of 10 to 16 slides from each gland were examined. The Gleason score was used for grading. Tumor volume was evaluated using a grid below the slides on which the tumor areas were previously sketched out. Tumor percentage was calculated by counting the number of squares on the grid involved by tumor and its relation to the number of squares of the entire area of the whole section on each slide. The mean percentage of tumor affecting the gland was considered and will be referred to as tumor volume in the text. The extraprostatic involvement was defined as tumor infiltrating the adipose tissue or neurovascular plexus. Only the parenchymatous infiltration of the seminal vesicle was considered positive. The tumors were divided into two groups for statistical comparison: favorable group which included tumors without extraprostatic involvement, seminal vesicle infiltration or lymph node metastasis, and the unfavorable group which included tumors with extraprostatic tissue involvement with seminal vesicle infiltration and/or lymph node metastasis.

\section{Immunohistochemistry}

Three-micrometer sections from paraffin-embedded specimens on adhesive-coated slides were submitted to heat antigen retrieval using a domestic microwave oven (high power) and citrate buffer, $\mathrm{pH}$ 6.0, 3 times, for 8 min (12). The endogenous peroxidase activity was quenched by exposing the sections to a solution of $\mathrm{H}_{2} \mathrm{O}_{2}$ for $5 \mathrm{~min}$. The sections were incubated overnight with anti-PCNA (PC10) and anti-p53 (DO-7) monoclonal antibodies (Dako, Carpinteria, CA) at 1:100 dilution in PBS at $4{ }^{\circ} \mathrm{C}$. Biotinylated antimouse immunoglobulin $\mathrm{G}$ was applied at 1: 400 dilution for $60 \mathrm{~min}$ at room temperature (RT). After rinsing with PBS for 30 min, slides were incubated with peroxidase-conjugated streptavidin at 1:400 dilution for $45 \mathrm{~min}$ at RT and then rinsed with PBS for $30 \mathrm{~min}$. Color was developed by incubating the slides with $0.06 \%$ diaminobenzidine in PBS for $15 \mathrm{~min}$; slides were then rinsed in tap water, counterstained with Harris hematoxylin, dehydrated and cover- 
slipped (13). One slide that best represented the tumor was selected and at least 500 cells in a "hot spot" area were counted with a high-power field light microscope. Only the dark nuclear staining was considered positive for PCNA and p53. The percentage of anti-PCNA-stained cells and 3 groups of $\mathrm{p} 53$ expression were used for statistical analysis. p53 expression was considered negative when less than $20 \%$ of cells were stained, low when p53 was between 20 to $50 \%$ and high when the percentage was higher than $50 \%$.

\section{Statistics}

The patients were divided into favorable and unfavorable groups considering invasion of periprostatic tissue, seminal vesicle infiltration and lymph node metastasis. Mean PCNA values were compared between these groups by the chi-square test. Differences among the three groups in p53 immune expression in relation to PCNA were evaluated by analysis of variance.

\section{Results}

Patient age ranged from 50 to 74 years (mean, 65 years; median, 67 years). The Gleason score was 3-6 in 32 patients (62.7\%) and 7-10 in 19 (37.3\%). The mean tumor volume was $23.8 \%$ (median, $20 \%$ ) ranging from 0.6 to $79 \%$. Twenty-six $(51 \%)$ patients had less than a $20 \%$ tumor volume and $25(49 \%)$ more than a $20 \%$ tumor volume. Thirty-three $(64.7 \%)$ patients were staged as T1-T2N0M0, $17(33.3 \%)$ as T3N0M0 and $1(2 \%)$ as T3N1M0. Extraprostatic tissue extension was observed in 13 patients $(25.5 \%)$, seminal vesicle involvement in $11(21.6 \%)$ and lymph node metastasis in only 1 case (2\%). The percent of anti-PCNA-stained cells ranged from 0.5 to $46 \%$ (mean, $12.4 \%$; median, $10 \%$ ) (Figure 1). Eleven patients (21.6\%) were in the unfavorable group and the PCNA value ranged from 3 to $29 \%$ (mean, $12.85 \%$; me- dian, $12 \%)$. The remaining cases $(78.4 \%)$ were in the favorable group, with PCNA ranging from 0.5 to $46 \%$ (mean, $12.28 \%$; median, $10 \%)$. There was no significant difference between groups $(\mathrm{P}=0.8460)$ (Table 1). In 8 tumors p53 was considered negative, in 21 there was low immune reactivity and in 22 high immune reactivity (Figure 2). Mean p53 levels were 45.9\%, ranging from 0 to $99 \%$ of positive cells. There was a statistically significant difference among the mean PCNA values of the three groups of p53 immune expression. Mean PCNA was $8.3 \%$ in the p53-negative

Table 1 - Proliferative cell nuclear antigen (PCNA) values of favorable and unfavorable groups considering extraprostatic involvement, seminal vesicle infiltration and lymph node metastasis.

$* \mathrm{P}=0.8460$. PCNA data are reported as percent of PCNA-stained cells.

\begin{tabular}{lllll}
\hline Group & \multicolumn{4}{c}{ PCNA (\%) } \\
\cline { 2 - 5 } & $\mathrm{N}$ & $\begin{array}{c}\text { Mean } \\
( \pm \mathrm{SD})\end{array}$ & Median & Range \\
\hline Favorable & 40 & $12.28 \pm 8.89^{*}$ & 10 & $0.5-46$ \\
Unfavorable & 11 & $12.85 \pm 7.08^{*}$ & 12 & $3.0-29$
\end{tabular}

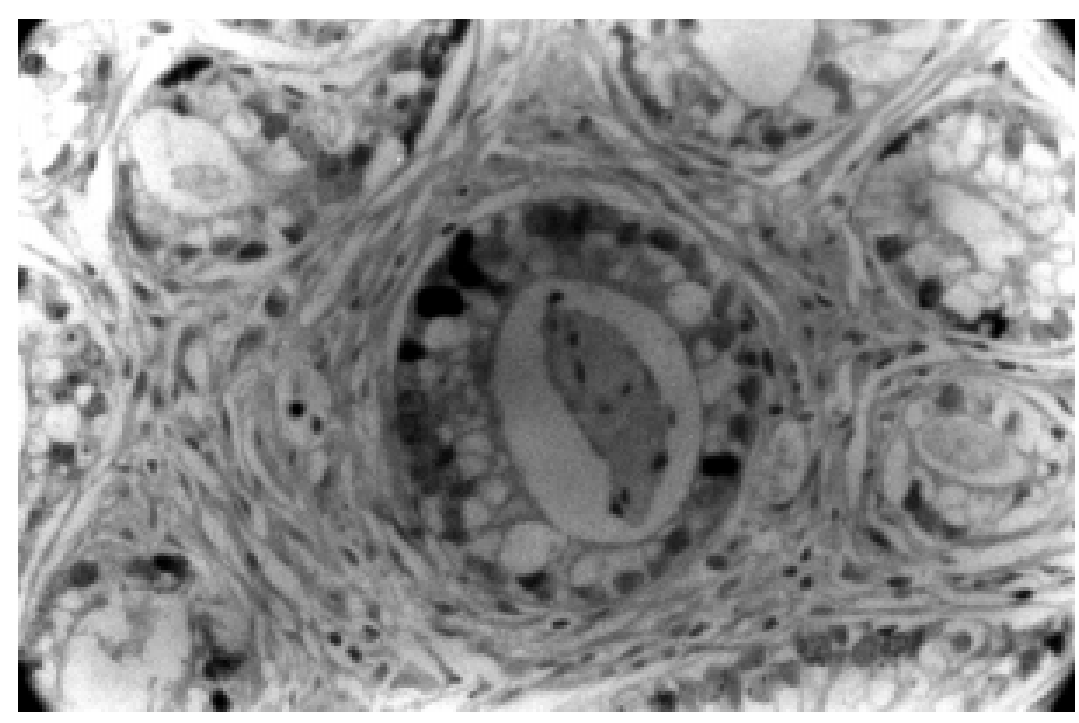

Figure 1 - Immunohistochemistry of a prostate adenocarcinoma using anti-PCNA (PC10) antibody. The dark nuclei are positive. 
group, $10.2 \%$ in the low expression group and $16 \%$ in the high expression group $(\mathrm{P}=$ 0.0226 ) (Table 2). No significant correlation was detectable between PCNA and any of the biological variables considered separately.

\section{Discussion}

The index of tumor cell proliferation can be used to define the behavior and prognosis in a series of human tumors, including breast cancer (14) and sarcomas (15). Proliferation activity in prostate can-

Table 2 - Proliferative cell nuclear antigen (PCNA) values and p53 immune expression.

PCNA data are reported as percent of PCNAstained cells. $* \mathrm{P}=0.0226$.

\begin{tabular}{lrrrr}
\multirow{2}{*}{$\begin{array}{l}\text { p53 } \\
\text { expression }\end{array}$} & \multicolumn{4}{c}{ PCNA (\%) } \\
\cline { 2 - 5 } & $\mathrm{N}$ & \multicolumn{1}{c}{$\begin{array}{c}\text { Mean } \\
( \pm \mathrm{SD})\end{array}$} & Median Range \\
\hline Negative & 8 & $8.31 \pm 4.89 *$ & 10.5 & $0.5-13$ \\
Low & 21 & $10.19 \pm 6.20^{*}$ & 9.0 & $1.0-29$ \\
High & 22 & $16.02 \pm 10.06 *$ & 15.5 & $4.0-46$
\end{tabular}

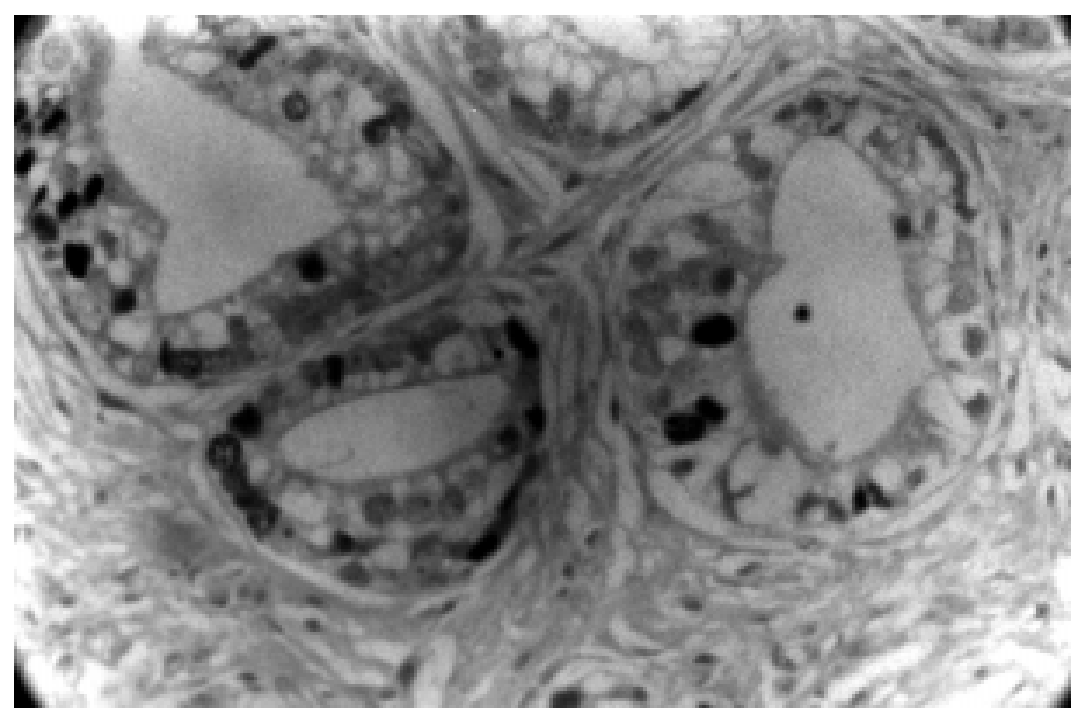

Figure 2 - Immunohistochemistry of a prostate adenocarcinoma using anti-p53 (DO7) antibody. Only the dark nuclei are considered to be positive. cer has been assessed by immunohistochemistry using Ki-67 monoclonal antibody $(16,17)$, PCNA $(18)$ and tritium $\left[{ }^{3} \mathrm{H}\right]$-thymidine or bromodeoxyuridine labeling $(19,20)$. Some studies demonstrated progressively rising levels of proliferative index (PI) values from PIN to invasive and metastatic carcinoma, illustrating the cancer progression $(19,20)$. The mean PI values have been shown to range from 1.7 to $17.6 \%$ indicating low cell turnover consistent with a natural slow disease progression. Visakorpi et al. (9), studying a heterogeneous group of patients including advanced metastatic disease using the same antibody (PCNA-PC10), found mean PI values ranging from 0.3 to $29.1 \%$ and established a strong association between proliferation and p53 immunoreactivity. We could also demonstrate a strong association between PI value and p53 expression in our cases and since only localized prostate cancers were selected a lower PI value was determined, with a mean PCNA value of $12.4 \%$ and a median of $10 \%$. Montironi et al. (18), also using PCNA antibody, found the same mean PI value in their cases and were able to correlate PI to histological grading. In our study we were unable to show a relationship between PI and Gleason grade, tumor volume or stage. Bubendorf et al. (21) obtained the same results using the MIB-1 antibody directed at recombinant parts of $\mathrm{Ki}-67$ to evaluate proliferation only in localized prostate adenocarcinoma. They found a mean PI value of $7.7 \%$ and were also unable to correlate proliferation with tumor stage or histological grade. The tumor growth results from high cellular proliferation and a low rate of cell death by apoptosis. The p53 protein coded by the p53 gene, localized on the short arm of chromosome 17, is important for the cell-cycle control. This protein acts as a DNA guardian allowing expression of DNA repair genes as well as promoting apoptosis (6). In more than $50 \%$ of human tumors the $\mathrm{p} 53$ protein is inactivated. The 
most common cause of p53 inactivation is missense mutation that promotes protein stabilization, allowing detection by immunohistochemistry (8). There are also alternative ways for inactivation: a) associations of p53 protein with other tumor suppressor genes such as WT1 and IRF1; b) inactivation by binding with oncoproteinlike adenovirus E1B and $\mathrm{Mdm} 2$ (murine double minute 2) protein (22), and c) destruction via a ubiquitin-dependent proteolytic pathway after binding to E6 protein, the product of human papillomavirus (HPV) 16 and 18 (23). We found p53 expression in $84 \%$ of our patients, with a mean value of $45.9 \%$. Bauer et al. (24) found almost the same proportion of p53 expression $(70.5 \%)$ using the same methodology, and the low or high expression was considered important to predict the relative risk of recurrence. The high level of nuclear p53 protein accumulation detected in our cases may be related to methodology since we used heat antigen retrieval with a microwave oven and citrate buffer, which considerably enhances antigen detection, unmasking antigenic epitopes $(25,26)$. This method was not mentioned in other studies $(9,10)$. We could not demonstrate a correlation between proliferation and biological parameters in localized prostate carcinoma, but we were able to find a strong relationship between PI and p53 protein expression $(P=0.0226)$, suggesting that $P 53$ mutation gives a proliferative advantage to a subgroup of these neoplasms.

\section{Acknowledgments}

We would like to thank Miss Maria Inês Rezende Meirelles for the technical support.

\section{References}

1. Bravo $R$, Frank $R$, Blundell PA \& Macdonald-Bravo H (1987). Cyclin/PCNA is the auxiliary protein DNA polymerasedelta. Nature, 326: 515-517.

2. Prelich G, Tan C-K, Kostura M, Mathews NB, So AG, Douney KM and Stillman B (1987). Functional identity of proliferating cell nuclear antigen and a DNA polymerase-delta auxiliary protein. Nature, 326: 517-520.

3. Idikio HA (1996). Expression of proliferating cell nuclear antigen in node-negative human prostate cancer. Anticancer Research, 16: 2607-2611.

4. Ahlgren G, Lindholm K, Falkmer U \& Abrahamsson P-A (1997). A DNA cytometric proliferation index improves the value of the DNA ploidy pattern as prognosticating tool in patients with carcinoma of the prostate. Urology, 50: 379-384.

5. Tamboli P, Amin MB, Schultz DS, Linden MD \& Kubus J (1996). Comparative analysis of the nuclear proliferative index (Ki67 ) in benign prostate, prostatic intraepithelial neoplasia and prostatic carcinoma. Modem Pathology, 9: 1015-1019.

6. Lane DP (1992). p53 Guardian of the genome. Nature, 358: 15-16.
7. Isaacs WB, Carter BS \& Ewing CM (1991). Wild-type p53 suppresses growth of human prostate cancer cells containing mutant p53 alleles. Cancer Research, 51: 4716-4720.

8. Levine AJ , Momand J \& Finaly CA (1991). The p53 tumor suppressor gene. Nature, 351: 453-456.

9. Visakorpi T, Kallioniemi OP, Heikkinen A, Koivula T \& IsolaJ (1992). Small subgroup of aggressive, highly proliferative prostatic carcinomas defined by p53 accumulation. J ournal of the National Cancer Institute, 84: 883-887.

10. Navone N, Troncoso P, Pisters LL, Goodrow TL, Palmer J L, Nichols WW, von Eschenbach AC \& Conti CJ (1993). p53 protein accumulation and gene mutation in the progression of prostate carcinoma. J ournal of the National Cancer Institute, 85: 1657-1669.

11. Shroder FH, Hermanek $P$, Denis L, Fair WR, Gospodarowicz MK and PavoneMacaluzo M (1992). The TNM classification of prostate carcinoma. Prostate, 4 (Suppl): 129-138.

12. Shi SR, Key ME \& Kalra KL (1991). Antigen retrieval in formalin-fixed paraffin-em- bedded tissues: An enhancement method for immunohistochemical staining based on microwave oven heating of tissue sections. J ournal of Histochemistry and Cytochemistry, 39: 741-748.

13. Taylor CR \& Cote RJ (1994). Immunomicroscopy: a diagnostic tool for the surgical pathologist. In: Major Problems in Pathology Series. Vol. 19. 2nd edn. W.B. Saunders, Philadelphia.

14. Leonardi E, Girlando S, Seio G, Mauri FA, Perrone G, Sampini S, Dalla Palma P and Barbareschi M (1992). PCNA and Ki-67 expression in breast carcinoma: correlation with clinical and biological variables. J ournal of Clinical Pathology, 45: 416-419.

15. Ueda T, Aozaca K, Tsujimoto M, Ohsawa M, Uchida A, Aoki Y, Ono K \& Matsumoto $K$ (1989). Prognostic significance of Ki-67 reactivity in soft tissue sarcomas. Cancer, 63: 1607-1611.

16. Raymond WA, Leong AS-Y, Bolt JW Milios J \& J ose J S (1988). Growth fractions in human prostatic carcinoma determined by Ki-67 immunostaining. J ournal of Pathology, 156: 161-167.

17. Galee MPW, Visser-DeJ ong E, ten Kate FJ W, Schroeder FH \& van der Kwast TH 
(1989). Monoclonal antibody Ki-67 defined growth fraction in benign prostate hyperplasia and prostatic cancer. Journal of Urology, 142: 1342-1346.

18. Montironi R, Galluzzi CM, Scarpelli M \& Diamanti L (1994). Quantitative characterization of the frequency and location of cell proliferation and death in prostate pathology. J ournal of Cellular Biochemistry, 19 (Suppl): 238-245.

19. Meyer J S, Sufrin G \& Martin SA (1982). Proliferative activity of benign human prostate, prostatic adenocarcinoma and seminal vesicle evaluated by thymidine labeling. J ournal of Urology, 128: 13531356.

20. Nemoto R, Uchida K, Shimazui T, Hattori
K, Koiso K \& Harada M (1989). Immunocytochemical demonstration of $\mathrm{S}$ phase cells by anti-bromodeoxyuridine monoclonal antibody in human prostate adenocarcinoma. J ournal of Urology, 141: 337340.

21. Bubendorf L, Sauter G, Moch H, Schmid HP, Gasser TC, J ordan P \& Mihatsch MJ (1996). Ki-67 labelling index: an independent predictor of progression in prostate cancer treated by radical prostatectomy. J ournal of Pathology, 178: 437-441.

22. Momand J \& Zambetti G (1997). Mdm-2: "Big Brother" of p53. J ournal of Cellular Biochemistry, 64: 343-352.

23. Werness BA, Levine AJ \& Howley PM (1990). Association of human papillomavi- rus types 16 e $18 \mathrm{E} 6$ proteins with p53. Science, 248: 76-79.

24. Bauer JJ, Connelly RR, Sesterhenn IA, Bettencourt M-C, McLeod DG, Srivastava S \& M oul J W (1997). Biostatistical modeling using traditional variables and genetic biomarkers for predicting the risk of prostate carcinoma recurrence after radical prostatectomy. Cancer, 79: 952-962.

25. Taylor CR, Shi S-R \& Cote RJ (1996). Antigen retrieval for immunohistochemistry. Status and need for greater standardization. Applied Immunohistochemistry, 4: 144-166.

26. Leong AS-Y, Milios J \& Leong J (1996). Epitope retrieval with microwaves. Applied Immunohistochemistry, 4: 201-207. 